\title{
28. SEISMIC STRATIGRAPHY AND SEDIMENTARY PROCESSES IN ORCA AND PIGMY BASINS 1
}

\author{
Arnold H. Bouma and Charles E. Stelting, Gulf Research and Development Company \\ and \\ Leg 96 Sedimentologists ${ }^{2}$
}

\begin{abstract}
The diapirically controlled continental slope off Louisiana shows an irregular bathymetry consisting of diapiric highs and intraslope basins. Two types of basins were drilled during Leg 96 . Site 619 is located in Pigmy Basin, which is an example of a blocked-canyon intraslope basin. Air-gun records show a basin fill characterized by several sets of cyclic seismic sequences. These are from bottom to top: a semitransparent zone (sandy turbidites?) often with chaotic reflectors (slumps?), overlain by slightly discontinuous, parallel reflectors (muddy turbidites?), and topped by distinct continuous reflectors (hemipelagic and pelagic deposits?). Similar, but thinner, sequences can be observed on higher frequency records. The cores indicate that lithologic variations can be correlated with the seismic characteristics. An angular discontinuity is commonly present between two acoustical sequences. Drilling in Pigmy Basin penetrated the upper two seismic sequences observed on air-gun $\left(80\right.$ in. $\left.^{3}\right)$ records.

Orca Basin (Site 618), an interdomal basin, is surrounded by diapirs that form a rim preventing bottom-hugging currents from entering. This basin is characterized by a 200 - $\mathrm{m}$-thick anoxic brine over the basin floor. The anoxic bottom sediments are underlain by normal gray deposits indicating oxic conditions. Good seismic resolution could not be obtained. It was discovered that a slump mass is located on top of the Holocene sediments. The cores were very gassy, making detailed visual observations impossible.

The initial drilling objectives for Site 618 were to core a complete upper Quaternary record for stratigraphic purposes and to study vertical trends in sedimentologic, geotechnical, and geochemical parameters to better understand this type of intraslope basin. Because the objectives could not be met in Orca Basin, the stratigraphic study was conducted in Pigmy Basin and those results were correlated with the sedimentologic studies and the seismic sequences.
\end{abstract}

\section{INTRODUCTION}

The irregular topography of the Texas-Louisiana continental slope is the product of active diapirism and associated faulting. Available bathymetric charts lack the necessary detail to portray exact shapes and amount of relief (Fig. 1), but they clearly show the extreme bathymetric complexity of the region (Holland, 1970; Sorensen et al., 1975; Martin and Bouma, 1978). Continuous seismic profiling (Moore and Curray, 1963; Ewing and Antoine, 1966) provided the first information on the subbottom characteristics. Drilling by industry for stratigraphic purposes revealed that most of the diapirs consist of salt (Lehner, 1969). The bathymetric depressions or "intraslope basins," located between the highs, are commonly several hundred meters deeper than the sill depth between the surrounding diapiric highs. These basins are commonly referred to as salt withdrawal basins.

\footnotetext{
${ }^{1}$ Bouma, A. H., Coleman, J. M., Meyer, A. W., et al., Init. Repts. DSDP, 96: Washington (U.S. Govt. Printing Office).

Addresses: (Bouma, Stelting, present address) Chevron Oil Field Research Company, P.O. Box 36506, Houston, TX 77236 .

Leg 96 sedimentologists include: James M. Coleman, Coastal Studies Institute, Louisiana State University, Baton Rouge, LA 70803; Michel Cremer, Laboratoire de Géologie et Océanographie, Laboratoire Associé au CNRS No. 197, Université de Bordeaux 1, 33400 Talence, France: Laurence I. Droz Laboratoire de Giodynamique Sous-Marine, 06230 Villefranche-sur-Mer, France; Audrey W. Meyer, Ocea Godynique Sous-Marine, 06230 Villefranche-sur-Mer, Fron ifie Marite cific Marine Geology, U.S. Geological Survey, Menlo Park, CA 94025; Suzanne O'Connell, Ocean Drilling Program, 500 University Drive West, Texas A\&M University, College Station, TX 77843; Kevin T. Pickering, Department of Geology, University of Leicester, Leicester LE1 7RH, United Kingdom; and Dorrik A. V. Stow, Geology Department, University of Nottingham, Nottingham NG7 2RD, United Kingdom.
}

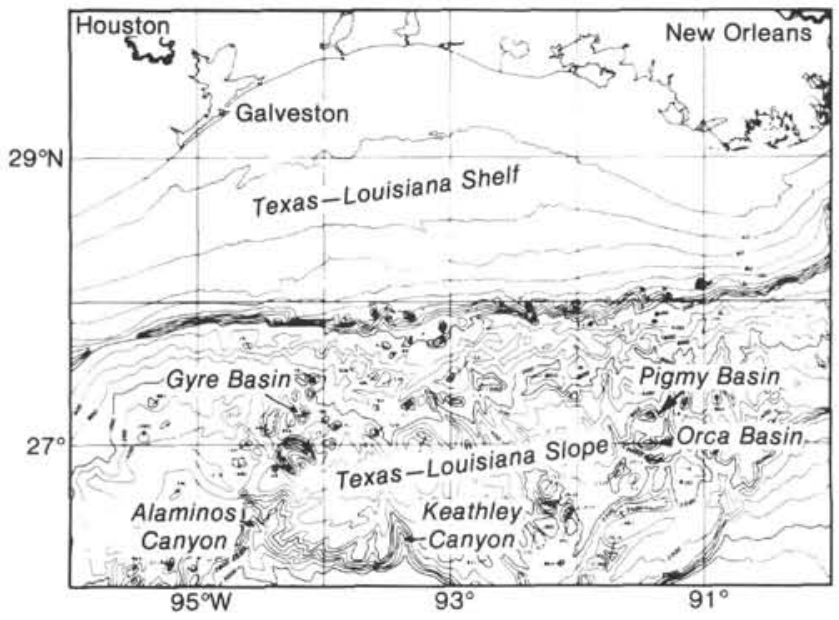

Figure 1. Regional bathymetric map of the northern Gulf of Mexico continental slope and location of Orca and Pigmy basins (contour interval is $200 \mathrm{~m}$, uncorrected).

Seismic studies have defined the general structure of several intraslope basins (Bouma et al., 1968, 1978, 1983; Antoine and Bryant, 1969, Lehner, 1969; Garrison and Martin, 1973). Lehner estimated that many intraslope basins, especially those on the upper slope, have accumulated at least $3000 \mathrm{~m}$ of Pleistocene sediment. Much of this sediment is believed to have slumped into the depressions during uplift of surrounding diapiric structures rather than having been transported by density flows and nepheloid layers (Bouma et al., 1978, 1983). 
The objectives of drilling in a few representative examples of these intraslope basins were to identify the characteristics of the upper $200 \mathrm{~m}$ of the sediment column, to establish a correlation between lithologies and seismic facies, to obtain a complete stratigraphic sequence of the late Neogene, and to analyze geotechnical and chemical properties for comparison with sediments in the more open areas of the Gulf of Mexico.

\section{TYPES OF INTRASLOPE BASINS}

High-resolution seismic reflection profiling, chemical and physical oceanographic vertical profiling, and sediment coring results have shown that two main types of intraslope basins exist: blocked-canyon basins and interdomal basins (Bouma, 1981, 1982; Bouma, Coleman and Meyer, this volume). Examples of the two types were drilled during Leg 96 in Pigmy Basin (Site 619) and Orca Basin (Site 618), respectively.

\section{Blocked-Canyon Intraslope Basins}

Blocked-canyon intraslope basins are defined as former submarine canyons or channels that became blocked by upward-moving diapirs which transformed the channel(s) into one or more oblong basins. The effectiveness of transport by bottom-hugging, sediment-laden currents and other mass movements decreased considerably or stopped completely if the sill between diapirs became too high. If the rate of diapiric uplift is less than the rate of infilling, such basins may become active conduits again. Transport and deposition of sediment can range from massive slumping and sliding, to debris flows and turbidity currents, and/or to pelagic and hemipelagic deposition.

Blocked-canyon intraslope basins typically display an acoustical sequence on seismic records (Bouma, 1981, 1982), with characteristic acoustical patterns (seismic facies) in both vertical and lateral directions. A complete acoustical sequence consists of three zones. The lower zone is acoustically semitransparent or chaotic, inferred to represent sandy material transported into the basin by fluidized slumps, debris flows, or high-density turbidity currents deposited during a low stand of sea level (Bouma, $1981,1982)$. The middle seismic zone contains rather weak, discontinuous, slightly irregular, parallel reflectors that may represent fine-grained turbidity current deposits emplaced during a rising sea level. The upper seismic zone is characterized by more or less continuous, distinct, parallel reflectors, interpreted to represent pelagic and hemipelagic sediments deposited during a high sea level stand (Bouma, 1981, 1982). The individual sequences are often separated by an angular discontinuity, implying active diapirism prior to the emplacement of the succeeding sequence. This diapiric activity may be caused by differences in the thickness of sediments deposited on the higher and lower flanks of the diapir, resulting in differential loading.

The vertical succession of acoustical reflector patterns in blocked-canyon intraslope basins may grade laterally. Such lateral changes support the interpretation that bottom transport of coarser material is confined to the deepest part of the channel.
Pigmy Basin is considered a representative example of a blocked-canyon intraslope basin (Fig. 1). It was selected for drilling during Leg 96 (Site 619) because of its well-developed seismic sequences and its proximity to the Mississippi Fan (Martin and Bouma, 1978; Feeley, 1982; Stelting, 1984). A total of 25 cores were obtained from Hole 619 to a sub-bottom depth of $208.7 \mathrm{~m}$. An alternate hole (619A) was drilled to a depth of $5.3 \mathrm{~m}$ for additional stratigraphic studies.

\section{Interdomal Intraslope Basins}

An interdomal basin is an intraslope basin that is isolated from its surroundings by diapirs that moved upward and coalesced sufficiently to prevent the entry of bottom-hugging density currents. Such a basin may have started as a more open basin before it became isolated by upward-moving diapirs.

The only studied example of an interdomal basin is Orca Basin (Shokes et al., 1977; Sackett, et al., 1977, 1979; Trefry and Presley, 1977; Trabant and Presley, 1978; McKee et al., 1978; Wiesenburg et al., 1979; Addy and Behrens, 1980; Bouma et al., 1980; Bouma, 1982; Feeley, 1982). Orca Basin was drilled during Leg 96 (Site 618) to collect data to test the many inferences implied from these diverse studies. A total of 11 cores were obtained from Hole 618 with a total depth (TD) at $92.5 \mathrm{~m}$ subbottom, and 3 cores from Hole $618 \mathrm{~A}$ for additional geochemical studies (TD $47.6 \mathrm{~m}$ ).

The steepness of the basin walls of Orca Basin has caused intensive slumping. Seismically, this results in hyperbolics and a lack of acoustic penetration. Insufficient recognizable reflectors are available to obtain an insight into the basin fill characteristics.

\section{PIGMY BASIN (Site 619)}

Pigmy Basin in a narrow, elongate blocked-canyon basin centered near latitude $27^{\circ} 11^{\prime} \mathrm{N}$ and longitude $91^{\circ} 25^{\prime} \mathrm{W}$. The basin is approximately $20 \mathrm{~km}$ long, $7 \mathrm{~km}$ wide, and trends northeast to southwest (Fig. 2). The surrounding ridge is at a water depth of about $1700 \mathrm{~m}$ and the basin floor at approximately $2300 \mathrm{~m}$. The long sides are very steep, up to $21.4^{\circ}$ (Feeley, 1982). The basin has a more gentle slope on its southern flank $\left(4.4^{\circ}\right)$. The northeastern side has not been surveyed (Fig. 3) (Kindinger and Bouma, 1981), thus the bathymetry is incomplete (Fig. 2).

\section{Seismic Characteristics}

Pigmy Basin exhibits seismic sequences typical of blocked-canyon intraslope basins (Bouma, 1981, 1982; Bouma et al., 1980, 1981). Air-gun (80 in. ${ }^{3}$ ) records show at least five seismic sequences, each generally less than $350 \mathrm{~ms}$ thick (Fig. 4). Each sequence is characterized by discontinuous to relatively continuous parallel reflectors that become more distinct in the upper part of each sequence. The lower part of the complete sequence, characterized by a transparent to semitransparent acoustic pattern with or without chaotic reflections, is missing from the two upper Pigmy Basin sequences.

An air-gun profile over Site 619 shows variations in amounts of sediment deposition and diapiric growth (Fig. 


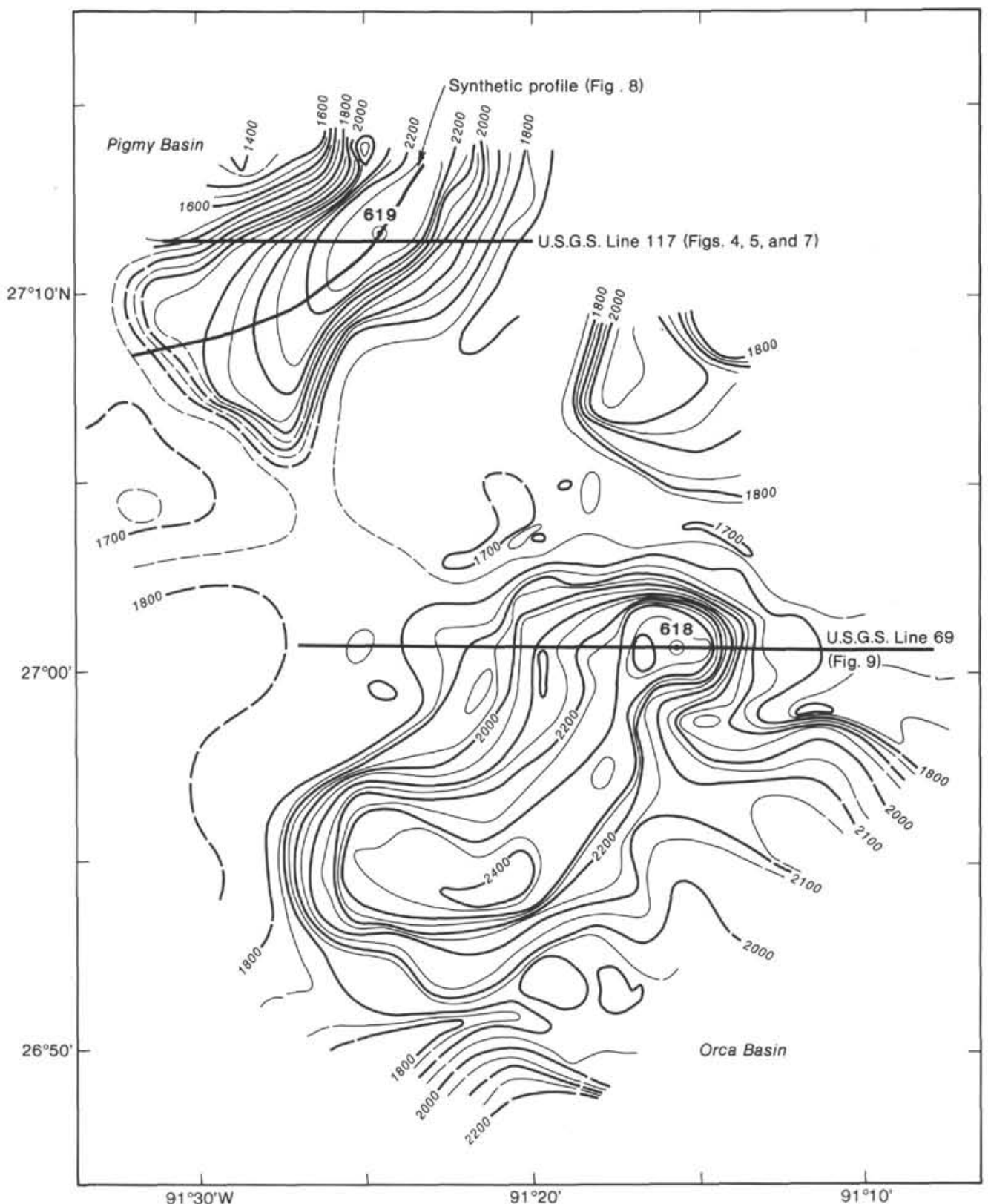

Figure 2. Bathymetry (in meters) of Pigmy and Orca basins, plus locations of seismic profiles shown in this chapter. Contour interval: $50 \mathrm{~m}$. Modified after Feeley, 1982.

4). The relatively uniform thickness of seismic Sequences 2,4 , and 5 suggests approximately equal rates of sediment delivery and uplift for most of the section. However, termination of reflectors onto the northwestern diapiric mass during Sequences 1 and 3 suggests that diapiric growth exceeded deposition near the end of Sequences 2 and 4.

The rate of diapiric activity varies in response to differential sediment loading (Bouma et al., 1980). The evidence for periodic diapiric activity is the angular disconformity that often is observed at the base of a seismic sequence. Figure 4 (Sequences 1, 3) and Figure 5 (Sequences 1B-D) show some of these disconformities rather distinctly.
Figure 5 presents a minisparker record over the same survey line as the air-gun record presented in Figure 4. The higher frequency of the minisparker system shows that the upper seismic sequence (Sequence 1) on the airgun record (Fig. 4) can be subdivided into five additional seismic sequences $(1 \mathrm{~A}-1 \mathrm{E})$. Each of the seismic sequences thin westward onto the diapiric ridge.

These sequences are characterized in the minisparker record by semitransparent (sT) or transparent $(\mathrm{T})$ reflectors which, in the basal part of the sequence, thin and onlap the lower boundary and by continuous, parallel reflectors $(\mathrm{Pc})$ which drape the top of each sequence (Fig. 5). Two other forms of parallel reflectors are observed in the minisparker records: discontinuous, paral- 


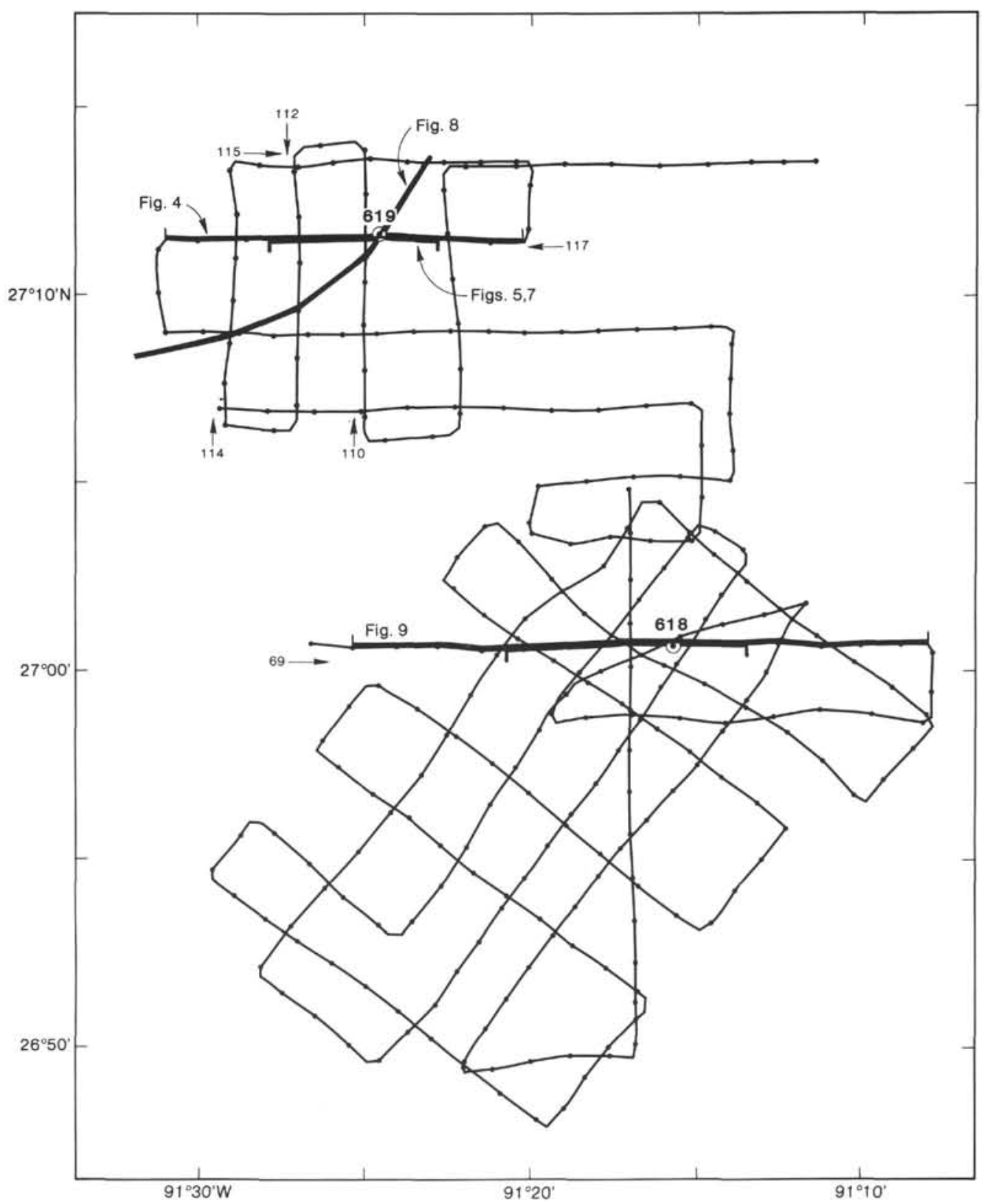

Figure 3. Location of seismic reflection profiles over Pigmy and Orca basins (U.S.G.S. Cruise Gyre-1980-4). Profiles in Figures 4, 5, and 7-9 indicated with bold lines.

lel reflectors $(\mathrm{Pd})$ which occur in association with the semitransparent intervals; and irregular, discontinuous parallel reflectors $(\mathrm{Pb})$ (typically chaotic in appearance), which characterize the top of seismic Sequence 2 (Fig. 5).

\section{Lithologic Characteristics}

The 208.7-m-thick series of predominantly fine-grained hemipelagic and pelagic sediments cored at Site $619 \mathrm{com}$ prises six lithologic units (see Site 619 chapter, this volume); these units correspond to seismic Sequences 1A to $1 \mathrm{E}$ and the upper part of Sequence 2 (Fig. 6). Textural variations (as determined by shipboard smear-slide analysis) are normally subtle, with each lithologic unit generally fining upward. These subtle fining-upward sequences often contain numerous intercalations of silt, sandy silt, silty sand, or sand. The coarser-grained layers show sedimentary structures described from fine-grained (muddy) turbidites (Stow and Shanmugam, 1980).

The three uppermost lithologic units $(0-93 \mathrm{~m}$ sub-bottom) are Holocene (0-5 m sub-bottom) to late Wisconsin in age (Kohl, this volume). These sediments are characterized by interbedded layers of either structureless or color-banded clay and silty clay. Thin silt or sand laminae, consisting mainly of foraminifer tests, occur randomly in all three units.

Structureless clays form the dominant lithology in lithologic Unit 1 (0-14.83 m sub-bottom; Core 619-1 to Sample $619-3-3,133 \mathrm{~cm}$ ), and comprise about $82 \%$ of the unit. The base of Unit 1 contains a 0.22 -m-thick interval of interbedded sand and clay. 


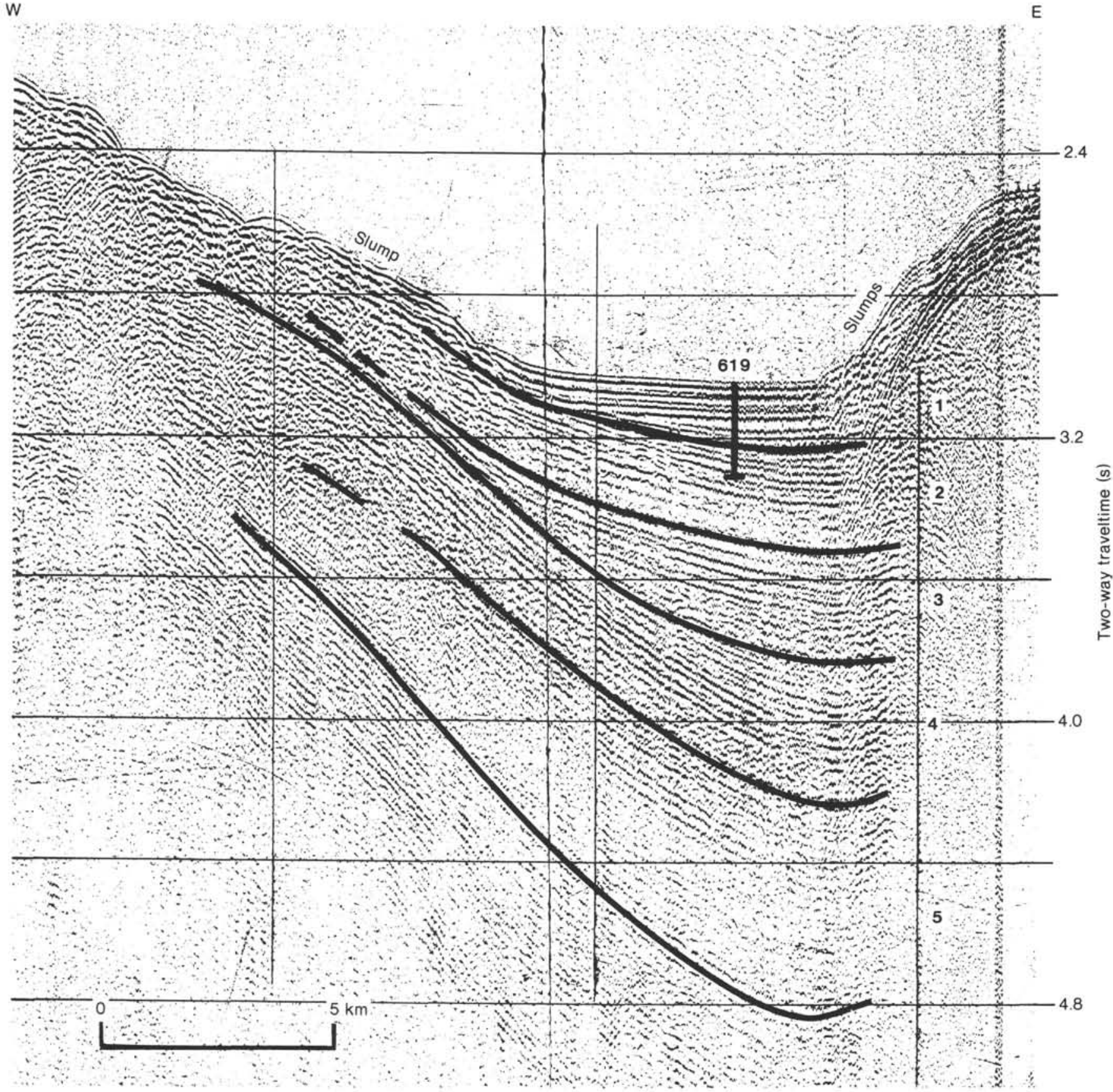

Figure 4. Air gun ( 80 in. $^{3}$; filtered frequency range: $30-80 \mathrm{~Hz}$ ) record (U.S.G.S. Line 117) over Pigmy Basin and location of Site 619 . Five major seismic sequences (1-5) are indicated. Distinct slump features are present on the west wall and less distinct ones on the eastern flank. Vertical scale in seconds (two-way traveltime). For location, see Figures 2 and 3.

Lithologic Unit 2 (14.83-65.34 m sub-bottom; Sample $619-3-3,133 \mathrm{~cm}$ to Core $619-8$ ) is characterized by a calcareous silty clay in the lower part and a calcareous clay in the upper part. Thin silty or sandy turbidite deposits were observed with a higher abundance in the lower part.

Lithologic Unit 3 (65.34-93.04 m sub-bottom; Cores 619-9 through 619-11) shows no systematic vertical trends in the calcareous clays and calcareous silty clays. Thin turbidite deposits occur relatively evenly throughout this unit.
Below $93 \mathrm{~m}$ sub-bottom, the color banding was no longer observed. Instead, the units are divisible by relatively systematic variations in grain size (i.e., subtle fining-upward sequences). Reduced core recovery in these lower lithologic units produced large gaps across which the boundaries of lithologic units could not be firmly established.

Lithologic Unit 4 extends from 93.04 to $116.8 \mathrm{~m}$ subbottom. These late Wisconsin glacial sediments consist predominantly of calcareous silty clays in the lower part (Core 13) and structureless, calcareous clays in the up- 


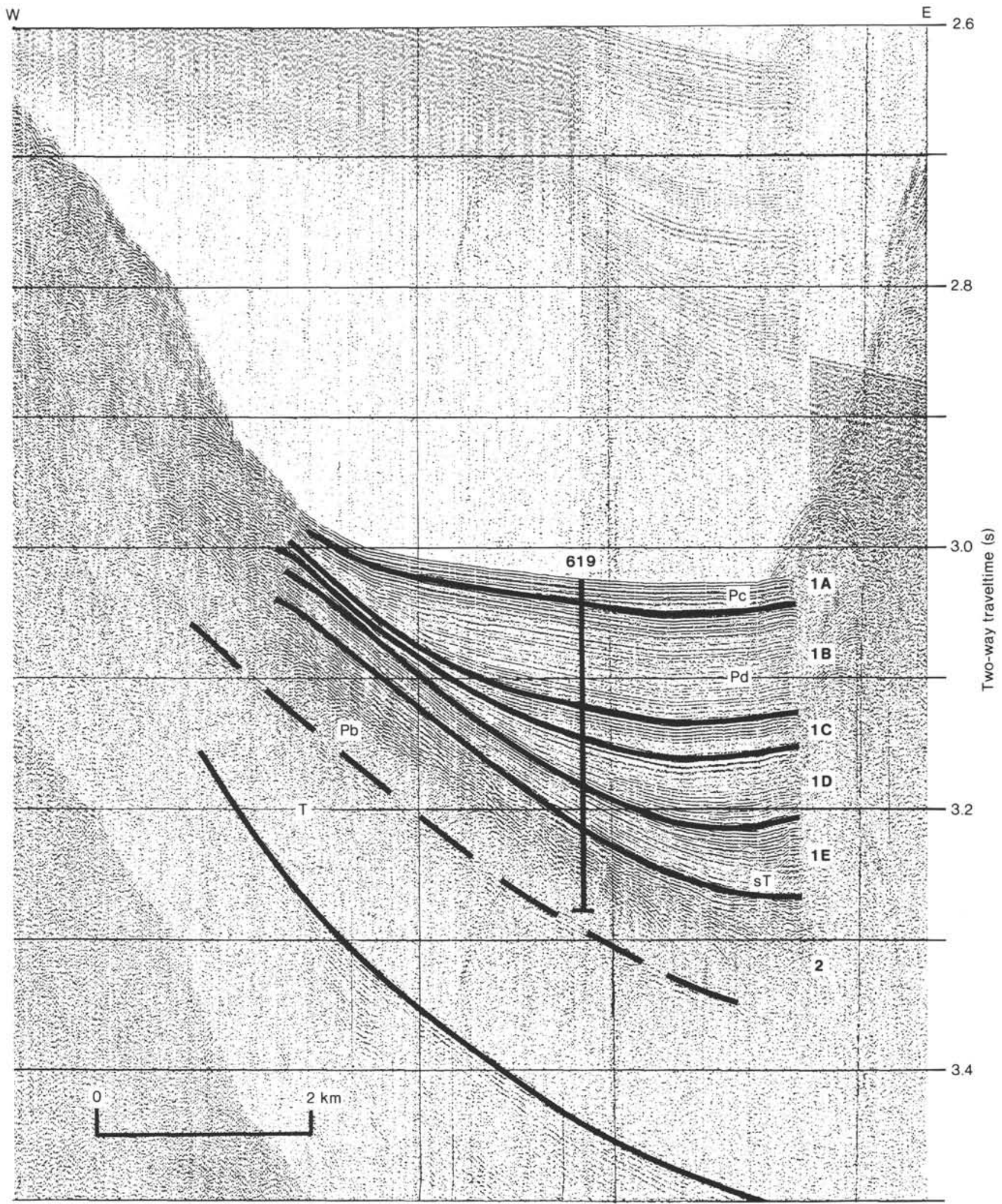

Figure 5. Minisparker (filtered frequency range: $200-500 \mathrm{~Hz}$ ) record of U.S.G.S. Line 117 over Pigmy Basin near the location of Site 619 . The upper seismic sequence (1) on the air-gun record (Fig. 4) can be divided into five smaller seismic sequences (1A-1E) on this higher frequency minisparker record. Seismic facies symbols: $\mathrm{Pb}=$ irregular, discontinuous parallel reflectors, $\mathrm{Pc}=$ continuous, parallel reflectors; $\mathrm{Pd}=$ discontinuous, parallel reflectors; $\mathrm{sT}=$ semitransparent reflections; and $\mathrm{T}=$ transparent reflections. Vertical scale in seconds (two-way traveltime). For location, see Figures 2 and 3. 


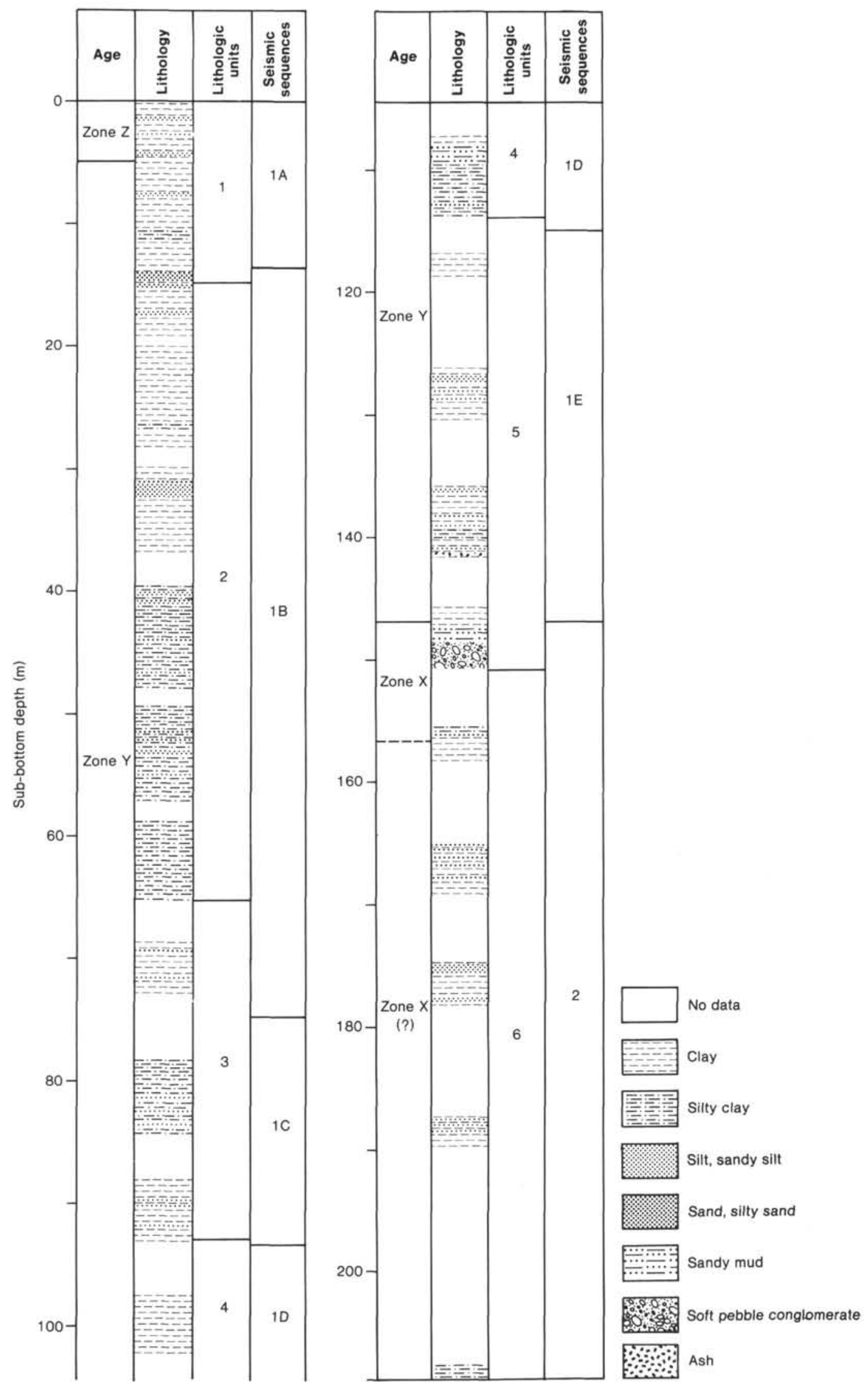

Figure 6. Lithologic summary, DSDP Site 619, showing sediment types, lithologic units, and corresponding seismic sequences (from minisparker record). Age information from Kohl (this volume). 
per part (Core 12). The presence of structureless sandy mud (108.14-109.27 m sub-bottom) and abundant, contorted, foraminifer-rich sand interbeds below $112.4 \mathrm{~m}$ sub-bottom suggests increased bottom transport.

The dominant lithology in lithologic Unit 5 (116.8$150.7 \mathrm{~m}$ sub-bottom; Cores 619-14 through 619-17) is clay. This clay alternates between dark and olive gray to a depth of $130.7 \mathrm{~m}$ sub-bottom, and is dark greenish gray below that depth. This color change seems to correspond to a significant reduction in the calcium carbonate content (Williams and Kohl, this volume). The clay in the uppermost core (116.8-119.2 $\mathrm{m}$ sub-bottom) is structureless, whereas in the middle of the unit (126.4$141.5 \mathrm{~m}$ sub-bottom; Cores 619-15 and 619-16) the clay is interbedded with silt or sand. The presence of a 2.26m-thick, contorted soft-sediment pebble conglomerate at the base of this unit, together with abundant thinbedded (muddy) turbidites in the middle part of this unit, suggest that diapiric activity influenced sedimentation at the beginning of seismic Sequence 1. Two thin ash layers (141.35-141.40 m sub-bottom) have been identified as the Y8 ash (Ledbetter, this volume). Volcanic shards were also observed in smear slides near the top and base of this unit; Ledbetter dated these dispersed ashes as the $\mathrm{Y} 6$ and $\mathrm{X} 2$ ashes.

Lithologic Unit 6 (150.7-208.7 m sub-bottom; Cores 619-18 through 619-25) corresponds to the seismically chaotic zone at the top of the seismic Sequence 2 (Wisconsin interstadial) (Fig. 5). Its sediment consists of interbedded clay, silt, and sand and contains the greatest abundance of coarse-grained material recovered at Site 619 . Unlike the younger (overlying) units, the silts and sand are mainly composed of terrigenous material, containing some foraminifers of shelfal origin (Kohl, this volume).

\section{Comparison of Seismic and Lithologic Facies}

One of the primary objectives for drilling Site 619 was to compare the lithologic characteristics with the cyclic seismic sequences observed in blocked-canyon intraslope basins. In earlier papers, Bouma $(1981,1982)$ and Bouma et al. (1983) suggested that the cyclic seismic sequences observed in blocked-canyon intraslope basins represent systematic changes in grain size (i.e., fining upward) related to transport processes that reflect sea-level fluctuations.

Although the lithologic variations observed in the upper $200 \mathrm{~m}$ at Site 619 are smaller than was originally anticipated, these variations do correlate quite well with the seismic sequences.

Figure 7 presents a correlation between the core lithologies and the minisparker seismic sequences. It should be noted that there are some discrepancies in sub-bottom depths between "corresponding" lithologic units and seismic reflectors; because interval velocities were used from the Mississippi Canyon area, the sediment types and vertical variations may prevent a precise matching. Generally speaking, the seismic sequences appear to reflect changes in grain size. This is especially true for seismic Sequences $1 \mathrm{~A}$ and 1B, where the parallel reflectors correspond to clay with rare muddy turbidites. The transparent acoustical facies at the base of Sequence 1A apparently is the product of interbedded sand and clay of turbidite origin. The semitransparent acoustical facies, which makes up the majority of Sequence 1B, consists predominantly of silty clay. The most obvious deviation occurs from the bottom of seismic Sequence 1B through Sequence 1C (corresponds to lithologic Unit 3) wherein the normal trends are reversed. The clays recovered at the base of Sequence 1B are slumped, which could account for the semitransparent seismic response. However, the lithofacies-to-seismic facies reversal in Sequence $1 \mathrm{C}$ apparently is affected by some parameter other than grain size. We suggest this change probably is reflective of the depositional processes.

Seismic Sequences 1D and $1 \mathrm{E}$ correspond to lithologic Units 4 and 5, respectively, and are both represented by fining-upward sedimentary sequences (Fig. 6). Lithologic Unit 4 (seismic Sequence 1D) grades upward from silty clay (slumped at base) and sandy mud to clay. Seismic Sequence 1E consists mainly of semitransparent reflectors; the draping parallel reflectors at the top are very thin. This seismic character is consistent with the sediments recovered in lithologic Unit 5 which grade upward from a soft-pebble conglomerate to sandy mud and is overlain by mainly thin muddy turbidites; the top of the unit corresponds to a thin, structureless clay.

Biostratigraphic results place the boundary between Ericson Zones Y and X at $147 \mathrm{~m}$ sub-bottom (Ericson and Wollin, 1968; Kohl, this volume). This concurs with the seismic results, which place the boundary between seismic Sequences 1 and 2 at about the same depth.

As noted above, core recovery within lithologic Unit 6 (seismic Sequence 2) was very poor. However, the interbedded nature of these coarser-grained deposits with clay are suggestive of more active bottom transport during this time. It is assumed that mass movement was more prevalent at the end of seismic Sequence 2, although this was observed only at about $189 \mathrm{~m}$ sub-bottom (slumped interbedded silt and clay). We believe, therefore, that the seismic character at the top of seismic Sequence 2 is consistent with the sediment recovered from this interval.

\section{Basin Evolution during the Late Wisconsin}

The grid of seismic data collected in 1980 by the U.S. Geological Survey provided good coverage over most of the basin floor (Fig. 3) (Kindinger and Bouma, 1981). However, the absence of a good longitudinal seismic line along the basin floor, together with the lack of seismic lines beyond the basin margins, hindered evaluations of seismic facies distribution and of basin evolution. In an effort to resolve this dilemma, we constructed a hypothetical longitudinal seismic profile across the basin floor using multichannel seismic lines as a reference and projecting the U.S. Geological Survey minisparker records into it (Fig. 8). Besides showing the inferred distribution of the seismic facies, this profile confirms closure of Pigmy Basin by diapiric uplift on the southwest end of the basin. A seismic line, which passes northeast of Pigmy Basin, also implies that closure occurred about simultaneously on the upslope (northeast) side of the ba- 


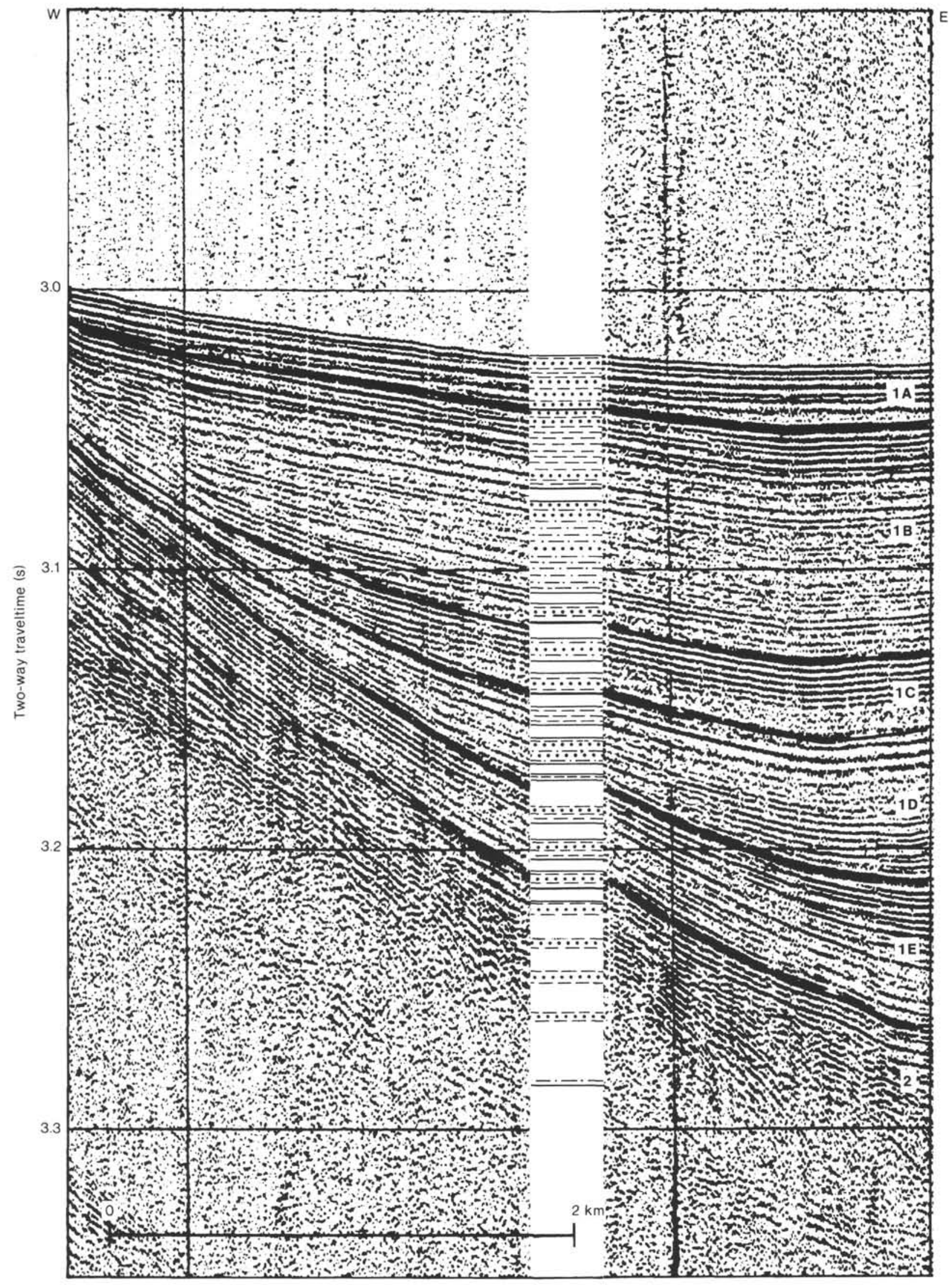

Figure 7. Comparison of seismic sequences (minisparker record from U.S.G.S. Line 117) and generalized lithofacies at Site 619. Seismic sequences are denoted by numbers $(1 \mathrm{~A}-1 \mathrm{E}, 2)$. Legend for lithologic symbols is the same as in Figure 6 . Location of seismic profiles shown in Figures 2 and 3. 


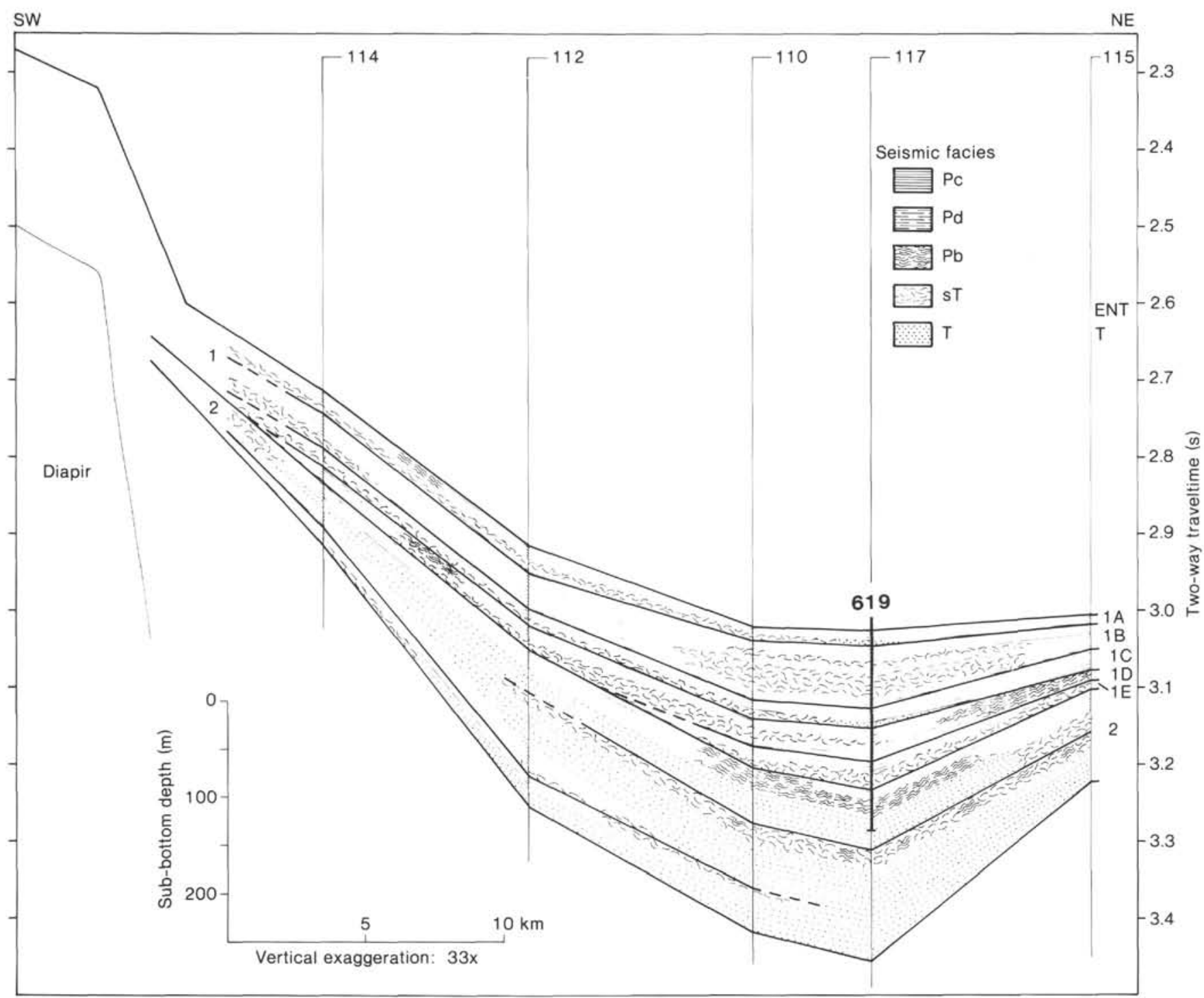

Figure 8. Constructed minisparker $(200-500 \mathrm{~Hz})$ seismic profile across the central basin floor of Pigmy Basin. Seismic facies symbols: $\mathrm{Pb}=$ irregular, discontinuous parallel reflectors; $\mathrm{Pc}=$ continuous, parallel reflectors; $\mathrm{Pd}=$ discontinuous parallel reflectors; $\mathrm{sT}=$ semitransparent reflections; and $\mathrm{T}=$ transparent reflections. Vertical scale in seconds (two-way traveltime). For location, see Figures 2 and 3.

sin; the amount of uplift was significantly smaller. (Line spacing was insufficient to continue construction of the profile beyond the U.S.G.S. grid).

Seismic records indicate that maximum sediment accumulation occurred in the northeastern end of Pigmy Basin. The relatively uniform thickness of seismic Sequence 2 across that part of the basin suggests that sedimentation rates exceeded rates of diapiric activity during the time interval represented by Sequence 2 (Figs. 4 and 5). The synthetic profile reveals that conditions differed on the southwest end of the basin. Significant thinning of this sequence onto the southwestern diapiric ridge suggests that uplift was relatively rapid during this time (Fig. 8).

Extensive transparent zones are the predominant seismic facies of Sequence 2. Two smaller sequence boundaries within seismic Sequence 2 are denoted by weak, parallel (discontinuous to irregular, discontinuous) reflectors or semitransparent reflectors.
The uppermost part of seismic Sequence 2 was penetrated at Site 619. The relatively high-amplitude, irregular, discontinuous parallel reflectors which occur at the top of the sequence correspond to thin-bedded turbidite deposits. These irregular, discontinuous parallel reflectors grade laterally to discontinuous parallel reflectors (Fig. 8). Such a distribution suggests that the coarsegrained material was deposited in the deepest part of the basin, whereas the southwestern side of the basin was probably receiving only finer-grained sediments.

The boundary between seismic Sequences 1 and 2 likely corresponds to the Ericson Zone Y/X boundary. Uplift of the diapiric mass to the northeast, as noted above, appears to have been most active at this time. Such uplift likely resulted in blockage of the basin within the Wisconsin interstadial (Zone X; Kohl, this volume). This is in agreement with lithologic and biostratigraphic results which support hemipelagic deposition as the primary mode of deposition during seismic Sequence 1. 
In addition to the change in depositional mechanism from Sequence 2 to 1 , the relationship between diapiric activity and sedimentation also changed during the late Wisconsin. Relatively rapid uplift of the southwestern salt mass evidently continued into Sequence 1 as denoted by the pinch-out of Sequence $1 \mathrm{E}$ onto the major sequence boundary (Fig. 8) and the relatively uniform thickness of Sequence 1E on the northeast side of the basin (Fig. 5). Above Sequence 1E, motion on the southwestern salt ridge appears to have slowed significantly, whereas diapiric motion along the northwestern ridge evidently increased (see thinning of seismic sequences in Fig. 5). The shift in diapiric activity was possibly in response to the loading produced by the thick sediment wedge on the northern end of the basin.

The distribution pattern of seismic facies in seismic Sequence 1 is denoted by a lateral grading of all facies except the draping, continuous parallel reflectors (Fig. 8 ). Such a lateral distribution suggests that the majority of coarser-grained (muddy turbidite) deposits in the late Wisconsin section are concentrated in the central (deep) part of the basin. Possible mass-movement events along the sides of the basin floor are implied by the semitransparent or transparent reflectors at the base of each seismic sequence and by the irregular, discontinuous parallel reflectors at the top of Sequences 1D and 1A (between Lines 112 and 114, Fig. 8). Considering that the sill on the northeastern side of the basin was not high and that the sediments do not contain any displaced shallow-water foraminifers, we conclude that the thin, muddy turbidites observed in the cores can have two potential origins. One is from the adjacent basin walls where muds were placed in motion as the result of instability resulting from diapiric uplift; surficial slumps ring the basin (see Fig. 4) and probably were also common deeper in the section (see also Kohl, this volume). The other origin may be the shelf, with only the upper parts of turbidity currents flowing over the updip sill.

In summary, we suggest that the larger seismic sequences $(1,2)$ are sea-level controlled. Seismic Sequence 1 corresponds to Ericson's Zone Y. The smaller seismic sequences indicate that deposition was not as regular as would be assumed if only sea level changes were the casual effect. Therefore, it is suggested that the smaller seismic sequences (1A-E) are the result of local mass movements induced by diapiric activity.

\section{ORCA BASIN (SITE 618)}

Orca Basin is located about $17 \mathrm{~km}$ SSE of Pigmy Basin. It is centered near $26^{\circ} 57^{\prime} \mathrm{N}$ latitude and $91^{\circ} 19^{\prime} \mathrm{W}$ longitude (Fig. 2). This interdomal basin is unique in that it contains a 200-m-thick anoxic brine over its floor. The interface with the overlying seawater is sufficiently sharp to show as a strong reflector on seismic records (Fig. 9). The first cruise to obtain bathymetric and highresolution seismic reflection data from this basin was conducted on Gyre in 1976 (Trabant and Presley, 1978). A more systematic cruise, using the same research vessel, was conducted in 1980 (Fig. 3). The 1980 cruise used a 80 -in. ${ }^{3}$ air-gun which provided deeper penetration but did not give the details of the near-surface sediments obtained in 1976 with a 700 Joule minisparker system.
Orca Basin is slightly arcuate in shape, about $25 \mathrm{~km}$ long and 5 to $6 \mathrm{~km}$ wide. The long axis of the basin trends northeast to southwest. The basin rim lies between 1700 and $1900 \mathrm{~m}$ water depth; the basin floor is located at a depth of about $2400 \mathrm{~m}$. Orca Basin consists of two major sub-basins, one on the northeast side and one near the southwest side, separated by a saddle in the center (Fig. 2). The detailed morphology is very irregular because of faults and slumps that occur on a scale too small to be incorporated in the bathymetric map (Feeley, 1982). The walls of the basin can be very steep and typically range from 5 to $19^{\circ}$.

\section{Seismic Characteristics}

The diapiric structures that flank the basin are marked by high-amplitude acoustic returns from their steeply dipping surfaces. Down-to-basin faults characterize the northeastern and northwestern basin ridges (Fig. 9), some with offsets as much as $0.1 \mathrm{~s}$ (Feeley, 1982). Although the abundance of these faults decreases around the southern side of the basin, this side of the depression is also characterized by the same type of tectonics. Some of the seismic records indicate a thickening of the section on the down-thrown side of the fault suggesting a growthfault character. The seismic reflection patterns suggest that most of the basin fill probably resulted from mass movement rather than from continuous pelagic and hemipelagic deposition. A discussion on these seismic characteristics is provided by Feeley (1982).

The distribution of seismic facies from high-resolution systems shows that the brine-covered area is sorrounded by a broad ring of incoherent reflectors that cover the inner flanks of the basin. This pattern can also be observed underneath the central part of the brine cover on some of the records. Along the outer rim of the basin, the incoherent pattern of reflectors change rather abruptly to a more layered pattern (Fig. 9). The change between both reflection patterns commonly coincides with the location of outer faults and slumps scars (Feeley, 1982).

\section{Lithologic Characteristics}

Site 618 was cored to a total depth of $92.5 \mathrm{~m}$ sub-bottom. The sediments are characterized by an abundance of reworked sediments. Microfaunal analyses indicate that the cored interval generally consists of interbedded massmovement and pelagic/hemipelagic deposits. The sediments consist of gray clay and silty clay with black, anoxic mud and silty/sandy intercalations (Fig. 10); they are highly disrupted by the presence of biogenic gas (Site 618 chapter, this volume). Gas hydrate crystals (a few millimeters in diameter) were recovered between 26 and $37 \mathrm{~m}$ sub-bottom (Burke et al., this volume).

The upper $16.1 \mathrm{~m}$ (Cores 619-1 and 618-2) contains a reworked Pleistocene fauna and is interpreted as a Holocene-emplaced mass-movement deposit (Site 618 chapter, this volume).

Sediments from 16.1 to $36.8 \mathrm{~m}$ sub-bottom (Core 618-3 through Section 618-5-1) consist of gray clay and silty clay with biogenic silt or sand intercalations (Fig. 10). The boundary between the Holocene and late Wisconsin glacial (Ericson Zones Z and Y, respectively) oc- 


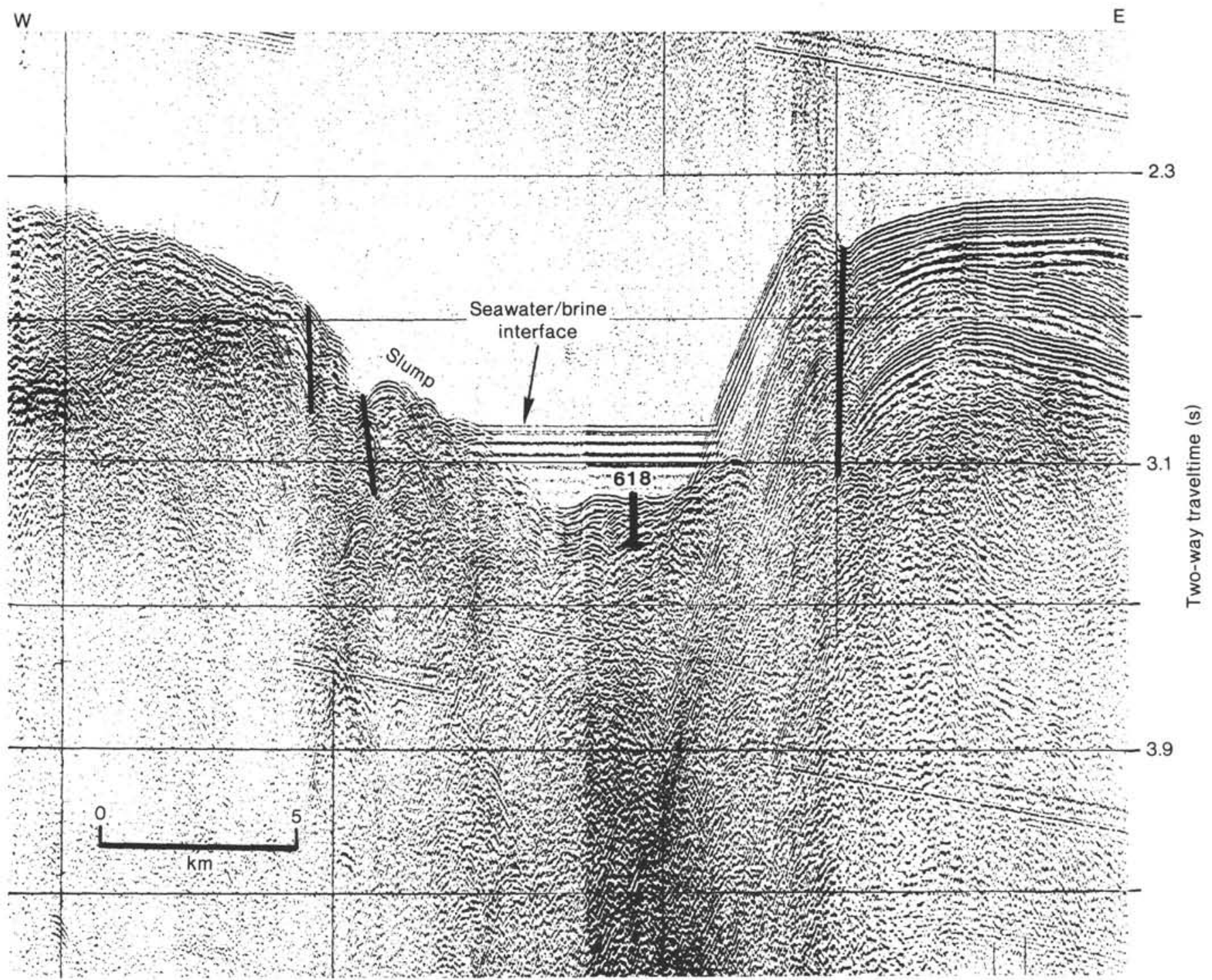

Figure 9. Air gun ( 80 in. $^{3}$ ) record (U.S.G.S. Line 69) over Orca Basin and location of Site 618. Vertical scale in seconds (two-way traveltime). For location, see Figures 2 and 3.

curs at about $30.2 \mathrm{~m}$ sub-bottom. The clay and silty clay intervals are characterized by alternating gray and black color bands in the Holocene; black banding is absent below that depth. Dark mud clasts (typically 1-2 mm in diameter) are dispersed throughout the muds. Thin coarser-grained layers $(0.5-1.0 \mathrm{~cm}$ thick) consist mainly of foraminifers, pteropod fragments, and other organic matter. Slumping, denoted by contorted layers in the cores, occurs from 17.70 to $18.55 \mathrm{~m}$ and 27.40 to 28.50 $\mathrm{m}$ sub-bottom. Most of the sandy layers occur within these slumpled intervals (Fig. 10).

The sediments from $36.8 \mathrm{~m}$ to the bottom of the hole at $92.5 \mathrm{~m}$ sub-bottom (Cores 618-5-1 through 618-11) consist mainly of gray clay. Interbedded coarse-grained layers (Fig. 10) are composed mainly of quartz (primary) and biogenic material. Most of these silt and sand layers occur within contorted intervals and likely are mass movement deposits.

Minimum sedimentation rates are $166.7 \mathrm{~cm} / 1000 \mathrm{yr}$. for the Holocene section $(0-31.6 \mathrm{~m})$ and $84.6 \mathrm{~cm} / 1000 \mathrm{yr}$. for the late Wisconsin glacial interval (Site 618 chapter, this volume).

\section{Basin Evolution during the Late Wisconsin}

The scientists on Leg 96 could not conclusively add to the late Wisconsin evolution of Orca Basin because a Holocene-emplaced slump body overlaid the original surficial sediments and because of the gassy nature of the deposits preventing good visual observations and the collection of paleomagnetic samples.

Because the black mud, representing highly anoxic, saline depositional conditions, was underlain by alternating zones of gray, oxic zones and black zones, the true bottom of the anoxic zone could not be established. Addy and Behrens (1980) carbon dated the black/gray contact in a piston core at $7910 \pm 170 \mathrm{yr}$. old, indicating that brine introduction started at that time. It is likely that brine was introduced several times. At this time we can only state that the interdomal nature of this basin, 

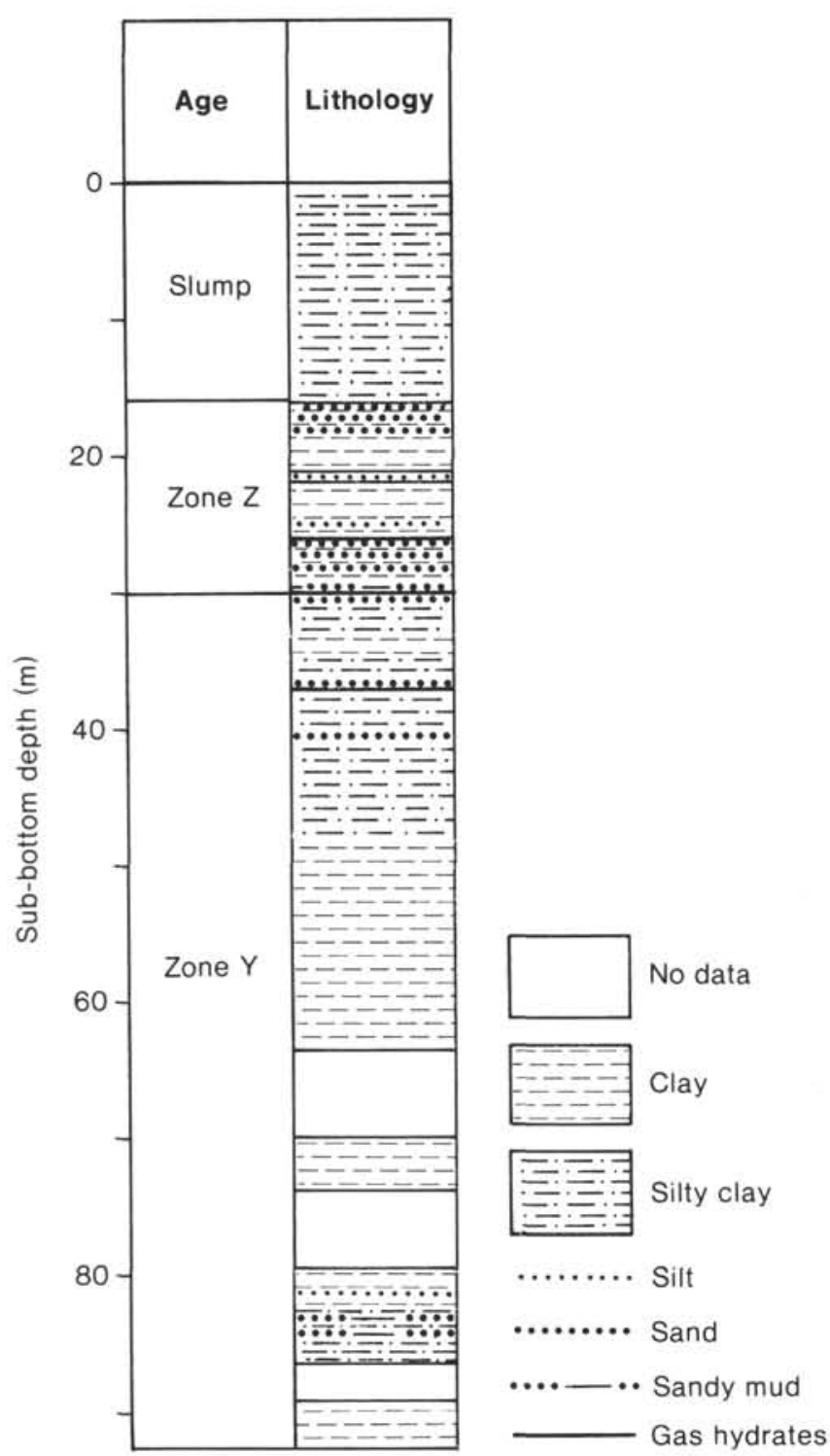

Figure 10. Generalized lithologic column, Site 618, with biostratigraphic zonation.

and thus the complete blocking off from bottom-transported sediment, started at least $8000 \mathrm{yr}$. ago.

\section{CONCLUSIONS}

During Leg 96 two intraslope basins in the Gulf of Mexico were drilled. Site 618 was located in an interdomal basin (Orca Basin) and Site 619 in a blocked-canyon basin (Pigmy Basin).

Because Site 618 proved to be covered by a slumped mass, no proper Holocene top of the underlying sediments could be established. Consequently, the objective of obtaining a good stratigraphic record of the late Wisconsin and Holocene was jeopardized. Therefore, it was impossible to establish sedimentologic or stratigraphic ground truth for chemical studies concerning the introduction of the brine and establishment of vertical chemical profiles. In addition, the gassy nature of the sediments made proper visual core descriptions inaccurate and any geotechnical studies inappropriate. The seismic records showed an abundance of hyperbolics, related to slumps. No proper acoustical returns could be collected to provide a proper framework for the upper sediments of this basin. The combination of all these factors led to the decision to abandon the hole before the permitted total depth was reached.

The stratigraphic objectives for Site 618 were added to the seismic response-lithologic characteristics comparative study planned for Site 619. Good data were obtained for a late Quaternary stratigraphic record, including paleontologic, oxygen-isotope, paleomagnetism, and tephrochronologic data. The characteristic vertical and lateral seismic sequence, typical for most blocked-canyon intraslope basins, could be correlated with lithologic differences in the cores. Although it was assumed that the sediments might range from sandy to clayey within each seismic sequence to provide sufficient impedance contrast needed to form seismic reflectors, the textural changes proved to be much smaller. However, small lithologic differences are sufficient to cause small variations in acoustic velocities. Those variations in lithology may be the reason that the depth of the seismic reflectors does not always coincide with the sub-bottom depths of lithologic changes.

In spite of the inaccuracies in direct correlation between seismic reflectors and lithologies, the results of the correlation between seismic facies and sediment types should be considered as positive (Figs. 6-8). Sediment characteristics from the cores recovered near the boundary of seismic Sequences 1 and 2 indicate slumped material. Paleontologic studies reveal that foraminifers from this interval are of shelfal origin. Thus, it can be concluded that Pigmy Basin was not a blocked-canyon intraslope basin during the Wisconsin interstadial. Blockage by diapiric activity must have occurred early during the late Wisconsin glacial (Ericson Zone Y).

\section{REFERENCES}

Addy, S. K., and Behrens, E. W., 1980. Time of accumulation of hypersaline anoxic brine in Orca Basin (Gulf of Mexico). Mar. Geol., $73: 242-252$.

Antoine, J. W., and Bryant, W. R., 1969. Distribution of salt and salt structures in Gulf of Mexico. Am. Assoc. Pet. Geol. Bull., 53: 2542-2550.

Bouma, A. H., 1981. Depositional sequences in clastic continental slope deposits, Gulf of Mexico. Geo-Mar. Lett., 1:115-121. 1982. Intraslope basins in northwest Gulf of Mexico: Key to ancient submarine canyons and fans. In Watkins, J. S., and Drake, C. L. (Eds.), Geologic Evolution of Continental Margins. Am. Assoc. Pet. Geol. Mem., 43:567-581.

Bouma, A. H., Bryant, W. R., and Antoine, J. W., 1968. Origin and configuration of Alaminos Canyon, northwestern Gulf of Mexico. Gulf Coast Assoc. Geol. Socs. Trans., 18:290-296.

Bouma, A. H., Feeley, M. H., Kindinger, J. L., Stelting, C. E., and Hilde, T. W. C., 1981. Seismic stratigraphic characteristics of upper Louisiana continental slope: an area east of Green Canyon. Proc. Ann. Offshore Technol. Conf., Houston, TX, Pap. 4098: 283-291.

Bouma, A. H., Martin, R. G., and Bryant, W. R., 1980. Shallow structure upper continental slope, Central Gulf of Mexico. Proc. Ann. Offshore Technol. Conf., Houston, TX, Pap. 3912:583-592.

Bouma, A. H., Smith, L. B., Sidner, B. R., and McKee, T. R., 1978. Intraslope basin in northwest Gulf of Mexico. In Bouma, A. H., Moore, G. T., and Coleman, J. M. (Eds.), Framework, Facies, and Oil-Trapping Characteristics of the Upper Continental Margin. Am. Assoc. Pet. Geol. Stud. Geol., 7:289-302. 
Bouma, A. H., Stelting, C. E., and Feeley, M. H., 1983. High-resolution seismic reflection profiles. In Bally, A. W. (Ed.), Seismic Expression of Structural Styles. Geol. Stud. Geol., 15:1.2.1-1-1.2.1-23.

Ericson, D. B., and Wollin, G., 1968. Pleistocene climates and chronology in deep-sea sediments. Science, 62:1227-1234.

Ewing, J. I., and Antoine, J. W., 1966. New seismic data concerning sediments and diapiric structures in Sigsbee Deep and continental slope, Gulf of Mexico. Am. Assoc. Pet. Geol. Bull., 50:479-504.

Feeley, M. H., 1982. Structural and depositional relationships of intraslope basin, northern Gulf of Mexico [M.S. thesis]. Texas A\&M University, College Station (unpublished).

Garrison, L. E., and Martin, R. G., 1973. Geologic structures in the Gulf of Mexico. U.S. Geol. Surv. Prof. Pap., 773:1-85.

Holland, W. C., 1970. Bathymetry maps, eastern continental margin, U.S.A., sheet 3 of 3, northern Gulf of Mexico. Am. Assoc. Pet. Geol. [scale 1: 1,000,000].

Kindinger, J. L., and Bouma, A. H., 1981. Single-channel, high-resolution seismic data from six areas of the northern Gulf of Mexico continental slope. U.S.G.S. Open-File Report 81-400 (microfilm).

Lehner, P., 1969. Salt tectonics and Pleistocene stratigraphy on continental slope of northern Gulf of Mexico. Am. Assoc. Pet. Geol. Bull., 53:2431-2479.

McKee, T. R., Jeffrey, L. M., Presley, B. J., and Whitehouse, U. G., 1978. Holocene sediment geochemistry of continental slope and intraslope basin areas, northwest Gulf of Mexico. In Bouma, A. H., Moore, G. T., and Coleman, J. M. (Eds.), Framework, Facies, and Oil-Trapping Characteristics of the Upper Continental Margin. Am. Assoc. Pet. Geol. Stud. Geol., 7:313-326.

Martin, R. G., and Bouma, A. H., 1978. Physiography of Gulf of Mexico. In Bouma, A. H., Moore, G. T., and Coleman, J. M. (Eds.), Framework, Facies, and Oil-Trapping Characteristics of the Upper Continental Margin. Am. Assoc. Pet. Geol. Stud. Geol., 7: 3-19.

Moore, D. G., and Curray, J. R., 1963. Structural framework of the continental terrace, northwest Gulf of Mexico. J. Geophys. Res., $68: 1725-1747$.
Sackett, W. M., Bernard, B. B., and Brooks, J. M., 1977. Chemical measurements in the Orca Basin sediments. EOS, Trans. Am. Geophys. Union, 58:1175 (abstract).

Sackett, W. M., Brooks, J. M., Bernard, B. B., Chung, H., and Parker, R. A., 1979. A carbon inventory for Orca Basin brines and sediments. Earth Planet. Sci. Lett., 4:73-81.

Shokes, R. F., Trabant, P. K., Presley, B. J., and Reid, D. F., 1977. Anoxic, hypersaline basin in the northern Gulf of Mexico. Science, 196:1443-1446.

Sorensen, F. H., Snodgrass, L. W., Rebman, J. H., Murchison, R. R., Jones, C. R., and Martin, R. G., 1975. Preliminary bathymetric map of the Gulf of Mexico region. U.S.G.S. Open-File Map 75140 [scale 1: $2,500,000$ ].

Stelting, C. E., 1984. Seismic stratigraphy and sedimentology of DSDP intraslope basin drill sites. Characteristics of Gulf Basin Deep-Water Sediments and Their Exploration Potential. Fifth Ann. Res. Conf., Gulf Section, Soc. Econ. Paleontol. Mineral. Found., Austin, Texas, Dec. 2-5: pp. 88-90.

Stow, D. A. V., and Shanmugam, G., 1980. Sequence of structures in fine-grained turbidites: comparison of recent deep-sea and adjacent flysch sediments. Sediment Geol., 25:23-42.

Trabant, P. K., and Presley, B. J., 1978. Orca Basin, anoxic depression on the continental slope, northwest Gulf of Mexico. In Bouma, A H., Moore, G. T., and Coleman, J. M. (Eds.), Framework, Facies, and Oil-Trapping Characteristics of the Upper Continental Margin. Am. Assoc. Pet. Geol. Stud. Geol., 7:303-311.

Trefry, J. H., and Presley, B. J., 1977. Transition metal chemistry in the Orca Basin. EOS, Trans. Am. Geophys. Union, 58:1175 (abstract).

Wiesenburg, D. A., Brooks, J. M., and Bernard, B. B., 1979. Biochemistry of reduced gases in the Orca Basin. EOS, Trans. Am. Geophys. Union, 60:283 (abstract).

Date of Initial Receipt: 21 February 1985

Date of Acceptance: 20 December 1985 